\title{
Effects of Sublethal Concentrations of Tobacco (Nicotiana Tobaccum) Leaf Dust on Some Biochemical Parameters of Hybrid Catfish (Clarias gariepinus and Heterobranchus Bidorsalis)
}

\author{
Kabir Mohammed Adamu ${ }^{* 2}$ and Ovie Kori-Siakpere ${ }^{1}$ \\ ${ }^{1}$ Department of Animal and Environmental Biology; Delta State University, P.M.B. 001; Abraka - Delta State - \\ Nigeria. ${ }^{2}$ Department of Biological Sciences; Ibrahim Badamasi Babangida University; P.M.B.11; Lapai - Niger \\ State-Nigeria
}

\begin{abstract}
The aim of this work was to study the effect of tobacco (Nicotiana tobaccum) leaf dust at sublethal concentrations (375.6, 187.8, $93.90 .0 \mathrm{mg} / \mathrm{L})$ on biochemical parameters of Hybrid catfish in a static semi-renewable bioassay system with the aim to ascertain its effect on the test fish after 14 days exposure period. The effects of the plant dust on the test fish was dose-dependent, revealing significant difference in albumin, glucose, triglyceride, cholesterol, urea, and uric acid of the serum, liver and kidney; total protein and globulin of serum and kidney and creatinine and calcium of the serum while insignificant difference were observed for calcium and creatinine in liver and kidney and total protein and globulin in liver compared to the control. The effect of the plant dust was most pronounced in the serum, less in the kidney and least in the liver. However, the monitored water quality parameters revealed that the plant dust had effects on primary productivity, thus the biodiversity of organisms.
\end{abstract}

Key words: Tobacco leaf dust, biochemical parameters, Hybrid catfish, serum, liver and kidney

\section{INTRODUCTION}

Aquaculture as an enterprise has some innate advantages, such as high returns, high productivity, high feed conversion ratio, utilization of agriculture and animal wastes, and high employment generation (Katiha, 2000). Aquaculture is increasingly becoming one of the fastest growing aspect of the plant industry worldwide (FAO, 2004). In semi-intensive system of farming, the management of water pond weeds is one of the most important aspects of a successful production system (Noga, 1996). However, the presence of predatory fishes, 'weed' fishes, chaoborus larva, tadpoles, frogs and leeches in fish culture ponds is a serious problem in aquaculture, which is due to their faster growth rate, as they share and better utilize the cultured habitats and their food (Jhingran, 1983). Therefore, the removal of predators/weed fishes from pond is necessary before the seed of cultured fish is added. To control these predators, fish farmers often use tobacco leaf to controlling these unwanted organisms/pests (Konar, 1970, Tobor,

\footnotetext{
*Author for correspondence: kabrmoh@yahoo.com
} 
1990). According to Aleem (1987), the use of tobacco leaf dust is due of its inexpensiveness, locally availability and easily degradable. Despite the wide use of this plant material, ecotoxicologists are interested in the ecotoxic properties of plant origin pesticides/piscicides, such that plant origin pesticides / piscicides cannot be used directly in freshwater bodies unless their toxicity and sublethal long term effect have been studied on non-target animals, sharing the habitat with the target animals.

The most valuable part / active ingredient of the plant used is the nicotine (Hassal, 1982). Nearly all the nicotine is produced in the root and transported to the leaves for storage. It is not clear why nicotine is produced by the plant other than it might be a relic of part of a growth or development process which has been lost in evolution (Akehurst, 1968). It is soluble in water, alcohol, chloroform, ether, kerosene and some fixed oils (Vogue, 1984). Tobacco leaf dust has been used in Nigeria as an effective insecticides and treatment of predators/pest in water (pond) as it is completely biodegradable (Aleem, 1987; Tobor, 1990).

Hybrid catfish is a hybrid of the African catfish Clarias gariepinus and Heterobranchus bidorsalis. They are omnivores which are desirable as food, thus are valuable species worldwide. They are one of the commercially important species of fish for rapid aquaculture expansion in Nigeria and elsewhere in the developing world.

Omoniyi et al., (2002) and Agbon et al., (2002) had reported the effect of tobacco leaf dust on Clarias sp. The control of mollusk in fish pond should be accomplished by using the tobacco waste (FAO, 1970). In Taiwan, tobacco waste dust is applied at 1 ton/acre as a pesticides and fertilizer in fish ponds (Jhingran, 1975). The choice of the test fish Hybrid catfish is attributed to the report of Rand et al., (1995) that in order to extrapolate the meaningful, relevant and ecological significant results from aquatic toxicity tests, not only appropriate test but also appropriate organism should be used, whenever, possible species should be studied that are indigenous to, or representative of the ecosystem that may be impacted thus, the choice of the Hybrid catfish constitutes one of the main fish species of economic importance in the Niger Delta Area of Nigeria and it is well known to fish farmers and consumers.

The knowledge of sublethal effects of xenobiotic compounds on biochemical parameters is very important to delineate the health of fish status and provide a future understanding of ecological impacts (Radhaiah et al., 1987). The activities of biochemical parameters are useful physiological 'markers' of damage to the organs such as the liver and hepatocytes (Chapatwala et al., 1982; Ngaha, 1982; and Akanji et al., 1993), thus the need to be assayed in the test fish.

This study was aimed to ascertain the assumption that tobacco leaf dust (Nicotina tobaccum) in a sublethal concentration and in a medium exposure time could influence the changes in the biochemical parameters (glucose, albumin, globulin, total protein, triglyceride, cholesterol, urea, uric acid, creatinine and calcium) in serum, liver and kidney of the test fish - Hybrid catfish and to confirm the most affected tissue/organ of the test fish using the examined biochemical parameters after the 14-day exposure period.

\section{MATERIALS AND METHODS}

\section{Experimental Fish}

Juvenile of the fish Hybrid catfish of mixed sex and the same brood stock: mean weight $(29.07 \pm 0.34 \mathrm{~g})$ and length $(17.35 \pm 0.23 \mathrm{~cm})$ were obtained from Asaba fish farm in Emede, Isoko Local Government Area of Delta State, Nigeria. They were transported to the Department of Animal and Environmental Biology Research Laboratory, Delta State University at the early hours of the morning $(6.00-8.00$ hour $)$ in a large plastic container. The fishes were acclimatized for 14 days during which they were fed to satiation with commercial fish feed pellets (copens $2.0 \mathrm{~mm}$ ) twice daily. Left over feed and faeces were siphoned off promptly and dead fish were promptly removed to avoid contamination. The percentage of death recorded during the acclimatization was less than $2 \%$. They were then transferred to the experimental plastic aquaria 10 fish/40L aquarium).

\section{Tobacco Leaf Dust}

The leaves of tobacco (Nicotiana tobaccum) were obtained from Apinko garden, Lokoja, Kogi State, Nigeria which was identified by Dr. S. M. Ayodele of the Department of Botany, Delta State University, Abraka, Nigeria. The collected sample leaves were sun dried for 14 days, grounded into powder with laboratory mortar and pestle and 
sieved then stored in a sealed plastic container until required. The concentrations of tobacco used were calculated as $50 \% 96 \mathrm{~h} \mathrm{LC}_{50}, 25 \% 96 \mathrm{~h} \mathrm{LC}_{50}$ and $12.5 \% 96 \mathrm{~h} \mathrm{LC}_{50}\left(96 \mathrm{~h} \mathrm{LC}_{50}\right.$ of tobacco leaf dust on the Hybrid catfish obtained from preliminary investigation was $751.2 \mathrm{mg} / \mathrm{L}$ ). Thus $375.6,187.8$ and $93.9 \mathrm{mg}$ of tobacco leaf dust were measured and homogenously mixed in one litre of water to give $375.6, \quad 187.8, \quad 93.9 \quad 0.0 \mathrm{mg} / \mathrm{L}$ concentration of the tobacco leaf dust. These concentrations were introduced into four sets of aquaria with one replication.

\section{Experimental Procedure}

Forty litres capacity plastic aquaria were maintained throughout the exposure period. Ten juveniles were placed in the aquarium. Bore-hole water was used during the acclimatization and exposure period. Feeding regime (0800 and $1800 \mathrm{~h}$ ) during the exposure period was the same as that of acclimatization period. In order to monitor the toxicant strength, level of dissolved oxygen, effects of evaporation; ammonia concentration and reduce stress during the experiment, the test media were replaced by $50 \%$ prepared - concentrations of the same quantity after removing its equivalent along with undigested food and defaecation every $48 \mathrm{~h}$ to maintain the requisite level and potency of the concentration. The exposure period lasted for 14 days during which some water quality parameters were monitored after $48 \mathrm{~h}$ with the exception of temperature which was determined every $24 \mathrm{~h}$ using the method described in APHA (1998). At the start $(0 \mathrm{~h})$ of the experiment, ten fishes were sacrificed and analyzed for the biochemical parameters.

\section{Sampling Techniques}

Blood was obtained from randomly selected 15 fishes each from the control and the exposed test after the 14 days exposure period using $2.0 \mathrm{ml}$ plastic syringe. This was done as described in Kori-Siakpere, (1998). The blood was transferred into a lithium heparin anticoagulant tube and allowed to clot at room temperature for $30-40$ minutes (Mahoba, 1987). Serum was thereof obtained by centrifugation using Hawkley centrifuge for 10 minutes at 3,000rpm (Ogbu and Okechukwu, 2001). The serum was transferred into anticoagulant free test-tube and stored in a refrigerator $\left(4^{\circ} \mathrm{C}\right)$ until analyses.
After blood collection, the fishes were sacrificed. The desired organs (liver and kidney) were removed and pulverized in a laboratory mortar and pestle while extractions were prepared by adding $2 \mathrm{ml}$ of $10 \%$ sucrose solution before been centrifuging (Mahoba, 1987) and stored in another test-tube in the refrigerator until analyses.

\section{Biochemical Parameters}

The biochemical parameters were determined using their respective kits (Cromatest Linear Chemicals Barcelona, Spain) in accordance with the manufacturer's instruction. The colorimetric method was used to determine the total protein (Biuret reaction), albumin, while total globulin was calculated with the following formula: Total globulin $(\mathrm{mg} / \mathrm{dL})=$ total protein - total albumin. Enzymatic colorimetric method was used to determine glucose, triglyceride, cholesterol, urea (urease/salycilate), uric acid and calcium was determined using total colorimetric method. Creatinine was determined in serum, liver and kidney using the kinetic colorimetric method.

\section{Data Analysis}

All data were presented as means \pm standard error, the data from the 14-day tobacco leaf dust exposure was first analyzed using a one-way (concentration) analysis of variance, after which individual means were compared using Bonferoni multi-sample correction/test. Control values obtained at the beginning and the end of the 14day exposure period were not significantly different and were therefore combined as one control. In all cases, the differences were considered statistically significant at either $p<0.01$ or $p<0.05$. All statistical analyses were performed using the software programme (GraphPad Prism ${ }^{\circledR}$ Software version 5.0, San Diego, CA).

\section{RESULTS}

\section{Water Quality Parameters}

The mean values of the water quality parameters of the different sublethal concentrations of tobacco ( $N$. tobaccum) leaf dust and control media to which the test fish Hybrid catfish were exposed over the 14 days exposure period is as presented in Table 1 The value of temperature and free carbon (iv) oxide, $\mathrm{pH}$ and dissolved oxygen significantly $(p<0.05)$ and $(p<0.01)$ decreased as the 
concentrations of tobacco leaf dust increased. However, the values of total alkalinity and conductivity in the exposed media significantly $(p<0.01)$ increased as the concentrations leaf dust increased compared to the control test.

Table 1 - Mean values ${ }^{\#}$ (SE) of Water Quality Parameters of the different sublethal concentrations of Tobacco (Nicotiana tobaccum) leaf dust and control to the test fish Hybrid catfish during the 14 days exposure period.

\begin{tabular}{lcccccc}
\hline CTLD $(\mathbf{m g} / \mathbf{L})$ & \multicolumn{5}{c}{ Water Quality Parameters } \\
\cline { 2 - 7 } & Temp $\left({ }^{\mathbf{O}} \mathbf{C}\right)$ & FCO $(\mathbf{m g} / \mathbf{L})$ & TAL $(\mathbf{m g} / \mathbf{L})$ & $\mathbf{p H}$ & DO $(\mathbf{m g} / \mathbf{L})$ & Cond $(\boldsymbol{\mu s} / \mathbf{c m})$ \\
\hline 0.00 & $30.63(0.34)$ & $1.85(0.12)$ & $0.25(0.02)$ & $7.15(0.06)$ & $6.62(0.00)$ & $146.47(0.37)$ \\
93.90 & $29.60(0.60)$ & $1.50(0.13)$ & $0.35(0.03)$ & $6.60(0.02)$ & $5.57(0.08)$ & $150.75(0.38)^{*}$ \\
187.80 & $28.77(0.34)^{*}$ & $1.25(0.17)^{*}$ & $0.47(0.06)^{*}$ & $6.27(0.02)^{* *}$ & $4.20(0.06)^{* *}$ & $154.80(0.90)^{* *}$ \\
375.60 & $28.77(0.34)^{* *}$ & $0.87(0.05)^{* *}$ & $0.570 .09)^{* *}$ & $6.07(0.02)^{* *}$ & $3.21(0.08)^{* *}$ & $167.42(1.23)^{* *}$ \\
\hline
\end{tabular}

\# - mean value obtained from 14 sampling with replicate; SE- standard error; CTLD- Concentration of Tobacco (Nicotiana tobaccum) leaf dust; Temp- Temperature; FCO- Free Carbon IV Oxide; TAL- Total Alkalinity; DO- Dissolved Oxygen; CondConductivity; $* \mathrm{P}<0.05$ and $* * \mathrm{P}<0.01$.

\section{Biochemical Parameters}

The mean values of total protein in the sampled tissue and organs of the Hybrid catfish are presented in Fig 1. There was an insignificant $(p>0.05)$ and significant $(p<0.01)$ decrease in the liver and (serum and kidney) total protein values as the concentration of tobacco leaf dust increased. Statistically, the kidney had the highest significant decrease while the least significant decrease was recorded in the liver when compared to the control.

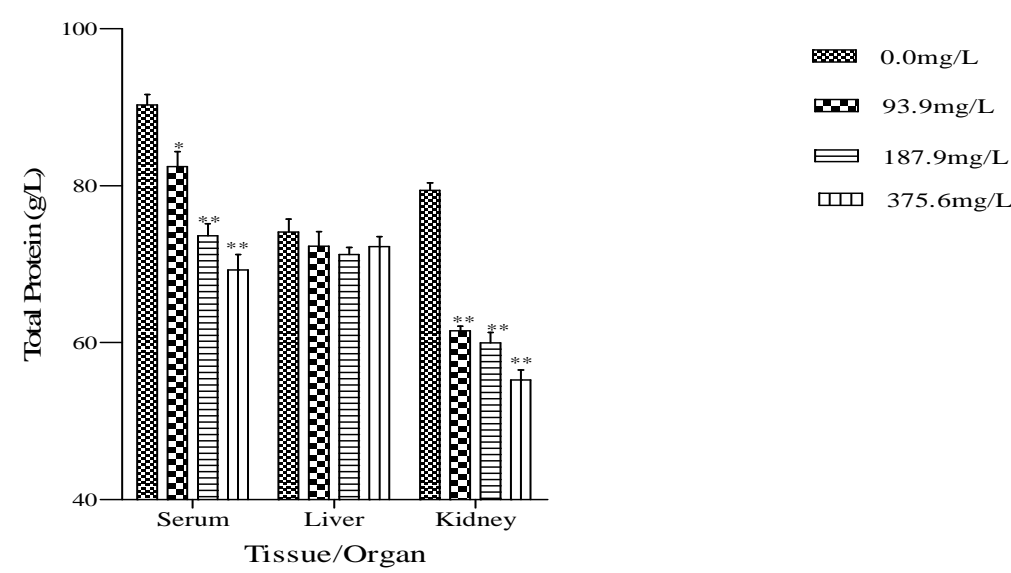

Figure 1 - Total protein values of test fish Hybrid catfish following 14days exposure to various sublethal concentrations of Tobacco ( $N$. tobaccum) leaf dust. Each column represents the mean value and vertical bars indicate the standard error of the mean. One asterisk represents significant difference between the control and experimental group at 0.05 level and two asterisks at 0.01 level.

The mean values of total albumin in the sampled tissue and organs of the Hybrid catfish are presented in Fig 2. There was significant $(p<0.01)$ decrease in serum and kidney with an increase in the liver total albumin values as the concentration of tobacco leaf dust increased. Statistically, the serum had the highest significant difference while the least significant difference was recorded in the liver when compared to the control. 


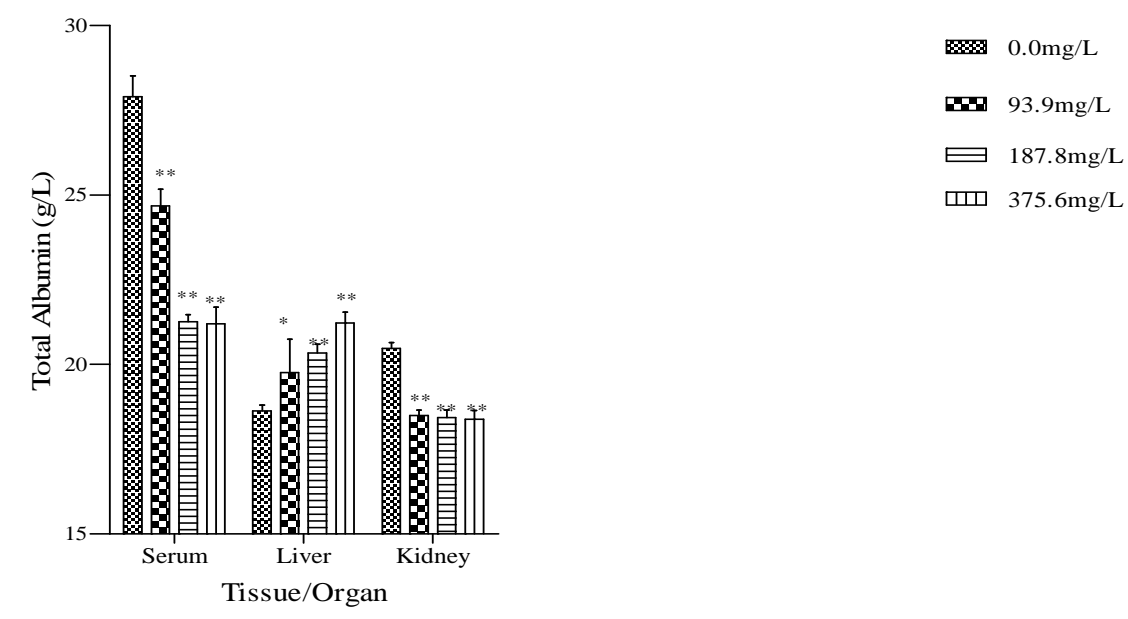

Figure 2 - Total albumin values of test fish Hybrid catfish following 14days exposure to various sublethal concentrations of Tobacco (N. tobaccum) leaf dust. Symbols as in Fig. 1.

The mean values of total globulin in the sampled tissue and organs of the Hybrid catfish are presented in Fig 3. There was significant $(p<0.01)$ decrease in the serum and kidney with an insignificantly $(p>0.05)$ decrease in the liver total globulin values as the concentration of tobacco leaf dust increased. Statistically, the kidney had the highest significant difference while the least significant difference was recorded in the liver when compared to the control.
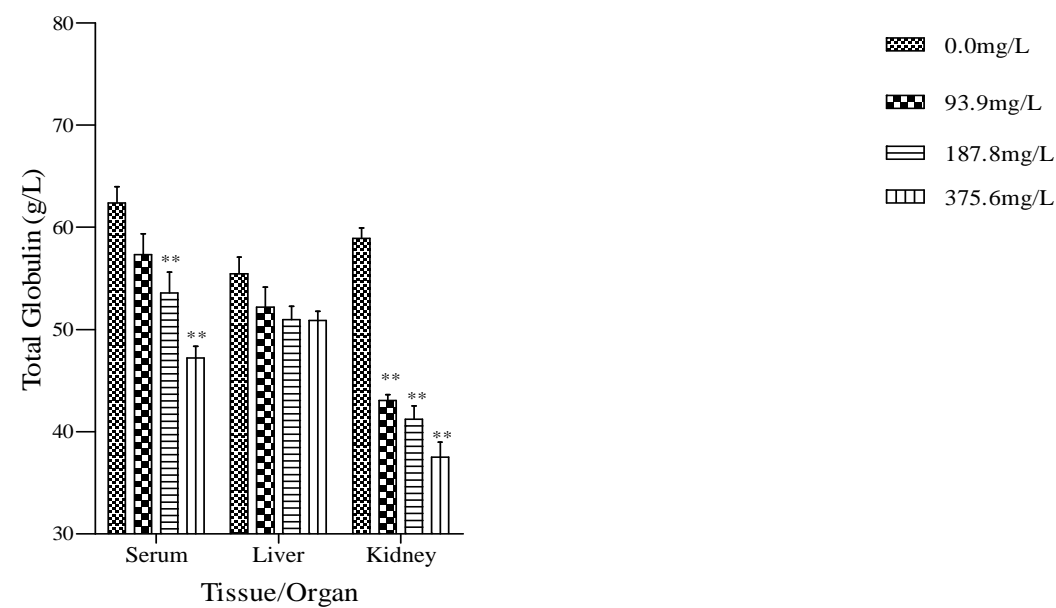

Figure 3 - Total globulin values of test fish Hybrid catfish following 14days exposure to various sublethal concentrations of Tobacco (N. tobaccum) leaf dust. Symbols as in Fig. 1.

The mean values of glucose in the sampled tissue and organs of the Hybrid Catfish are presented in Fig 4. There was significant $(p<0.01)$ decrease in the liver and kidney glucose values with significant $(p<0.01)$ increase in the serum glucose values as the concentrations of tobacco leaf dust increased. Statistically, the kidney had the highest significant difference while the least significant difference was recorded in the serum when compared to the control. 

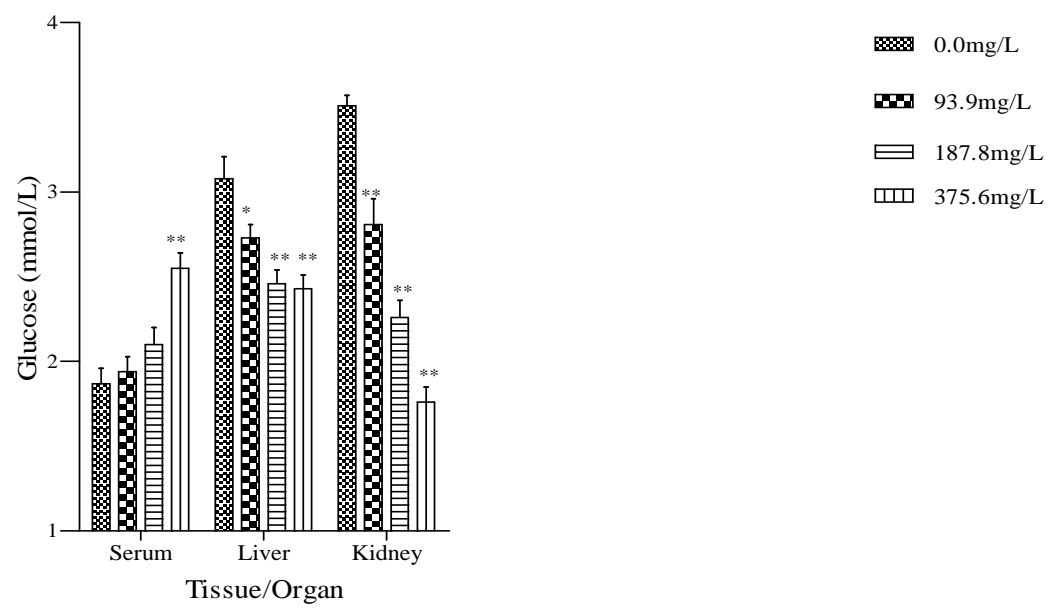

Figure 4 - Glucose values of test fish Hybrid catfish following 14days exposure to various sublethal concentrations of Tobacco (N. tobaccum) leaf dust. Symbols as in Fig. 1

The mean values of triglyceride in the sampled tissue and organs of the Hybrid catfish are presented in Fig 5. There was significant $(p<0.01)$ decrease in the serum and liver with significant $(p<0.01)$ increase in the kidney triglyceride values as the concentrations of tobacco leaf dust increased. Statistically, the serum had the highest significant difference while the least significant difference was recorded in the liver when compared to the control.

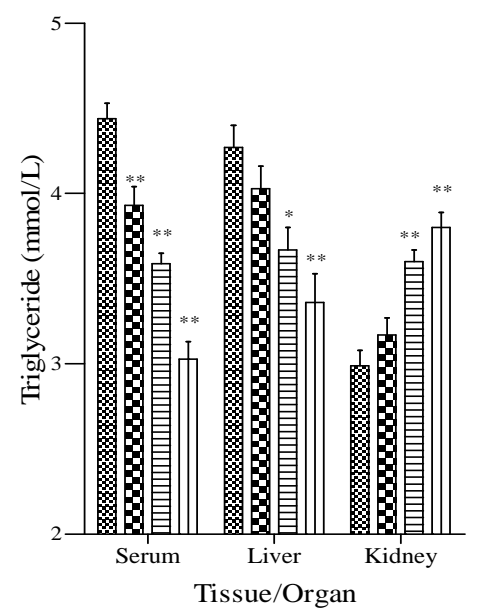

$$
\begin{aligned}
& \$ 0.0 \mathrm{mg} / \mathrm{L} \\
& \text { 93.9mg/L } \\
& \text { 己 } 187.8 \mathrm{mg} / \mathrm{L} \\
& \text { 피 } 375.6 \mathrm{mg} / \mathrm{L}
\end{aligned}
$$

Figure 5 - Triglyceride value of test fish Hybrid Catfish following 14days exposure to various sublethal concentrations of Tobacco (N. tobaccum) leaf dust. Symbols as in Fig. 1.

The mean values of cholesterol in the sampled tissue and organs of the Hybrid catfish are presented in Fig 6. There was significant $(p<0.01)$ decrease in the serum and liver with significant $(p<0.01)$ increase in the kidney cholesterol values as the concentrations of tobacco leaf dust increased. Statistically, the serum had the highest significant difference while the least significant difference was recorded in the kidney when compared to the control. 


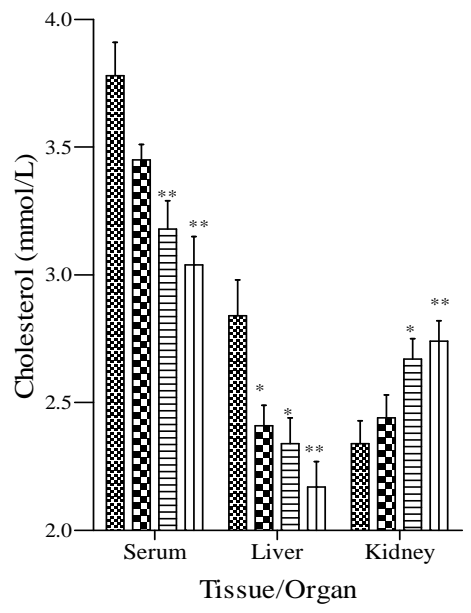

$$
\begin{array}{cc}
0.0 \mathrm{mg} / \mathrm{L} \\
03.9 \mathrm{mg} / \mathrm{L} \\
0187.8 \mathrm{mg} / \mathrm{L} \\
\text { س } 375.6 \mathrm{mg} / \mathrm{L}
\end{array}
$$

Figure 6 - Cholesterol values of test fish Hybrid catfish following 14days exposure to various sublethal concentrations of Tobacco (N. tobaccum) leaf dust. Symbols as in Fig. 1.

The mean values of calcium in the sampled tissue and organs of the Hybrid catfish are presented in Fig 7. There was significant $(p<0.01)$ decrease in the serum with insignificant $(p>0.05)$ decrease in the liver and kidney calcium values as the concentrations of tobacco leaf dust increased. Statistically, the serum had the highest significant difference while the highest insignificant difference was recorded in the kidney when compared to the control.

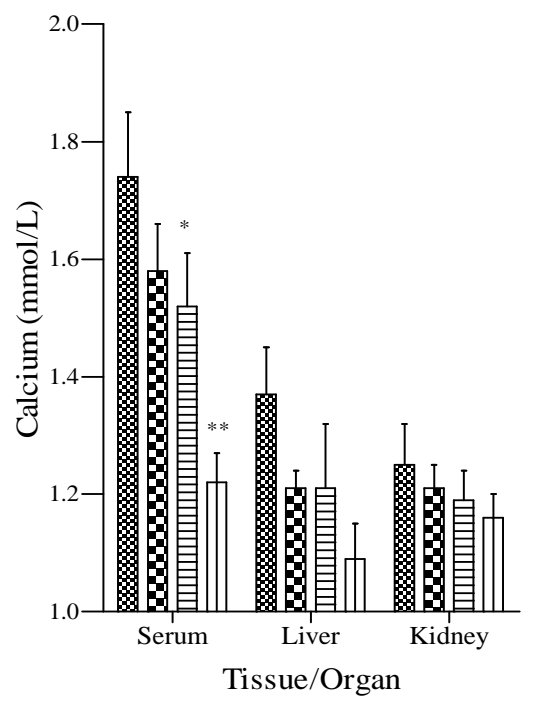

$$
\begin{aligned}
& \text { \$8 } 0.0 \mathrm{mg} / \mathrm{L} \\
& \text { 푸 } 93.9 \mathrm{mg} / \mathrm{L} \\
& \text { 戸 } 187.8 \mathrm{mg} / \mathrm{L} \\
& \text { एल } 375.6 \mathrm{mg} / \mathrm{L}
\end{aligned}
$$

Figure 7 - Calcium values of test fish Hybrid catfish following 14days exposure to various sublethal concentrations of Tobacco (N. tobaccum) leaf dust. Symbols as in Fig. 1.

The mean values of creatinine in the sampled tissue and organs of the Hybrid catfish are presented in Fig 8. There was an insignificant $(p>0.05)$ decrease and increase in the liver and kidney whilst the serum recorded significantly $(p<0.01)$ decreased in the creatinine values as the concentrations of tobacco leaf dust increased. Statistically, the serum had the highest significant difference while the highest insignificant difference was recorded in the kidney when compared to the control. 


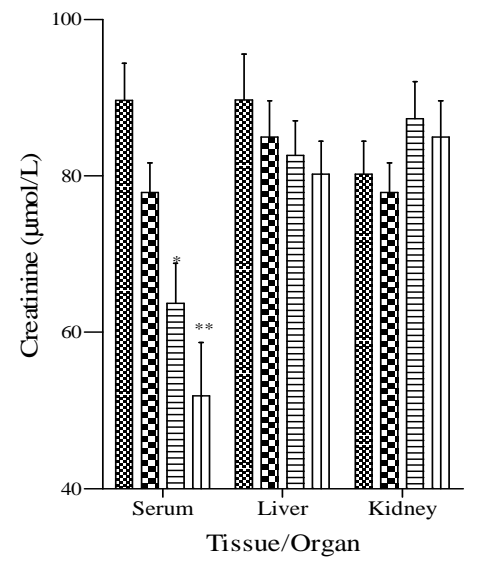

$$
\begin{array}{ll}
\approx & 0.0 \mathrm{mg} / \mathrm{L} \\
\square & 93.9 \mathrm{mg} / \mathrm{L} \\
\rightleftharpoons & 187.8 \mathrm{mg} / \mathrm{L} \\
\square & 375.6 \mathrm{mg} / \mathrm{L}
\end{array}
$$

Figure 8 - Creatinine values of test fish Hybrid catfish following 14days exposure to various sublethal concentrations of Tobacco (N. tobaccum) leaf dust. Symbols as in Fig. 1

The mean values of urea in the sampled tissue and organs of the Hybrid catfish are presented in Fig 9. The urea concentration decreased significantly $(p<0.01)$ in the serum and kidney but increased significantly $(p<0.01)$ in the liver as the concentrations of tobacco leaf dust increased. Statistically, the kidney had the highest significant difference while the least significant difference was recorded in the liver when compared to the control.
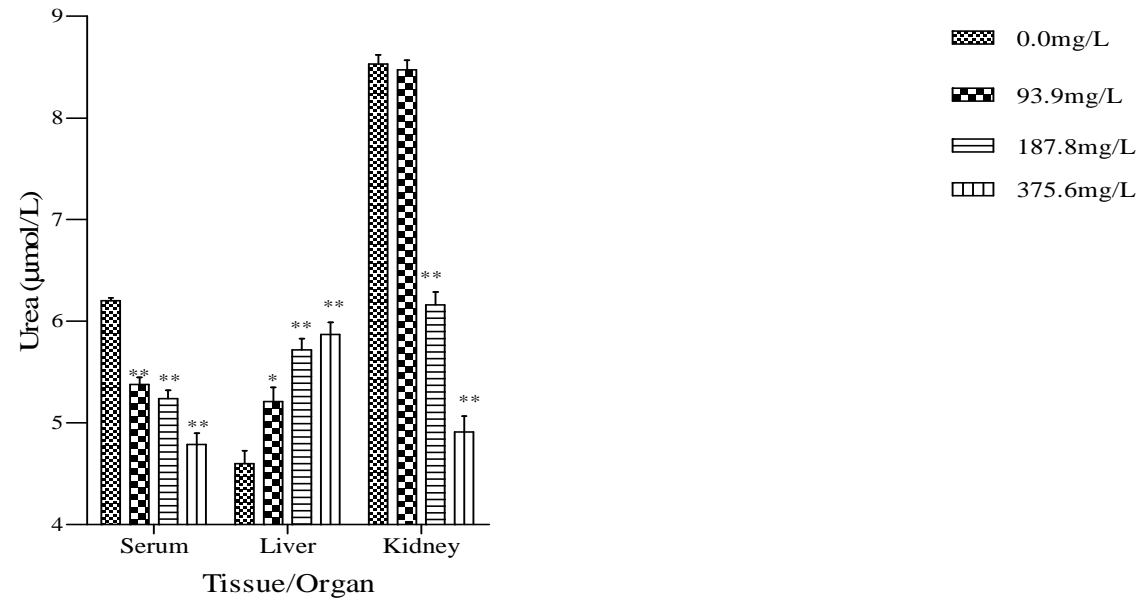

Figure 9 - Urea values of test fish Hybrid catfish following 14days exposure to various sublethal concentrations of Tobacco (N. tobaccum) leaf dust. Symbols as in Fig. 1.

The mean values of uric acid in the sampled tissue and organs of the Hybrid catfish are presented in Fig 10. The amount of uric acid in the serum and kidney decreased significantly $(p<0.01)$ but increased significantly $(p<0.01)$ in the liver as the concentrations of tobacco leaf dust increased. Statistically, the liver had the highest significant change while the least significant change was recorded in the serum when compared to the control. 


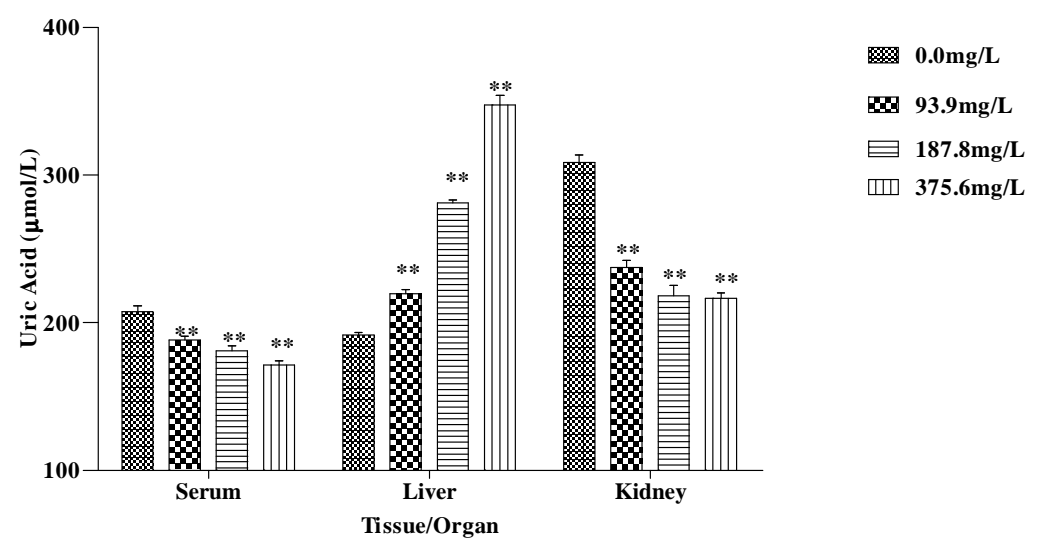

Figure 10 - Uric acid values of test fish Hybrid catfish following 14days exposure to various sublethal concentrations of Tobacco (N. tobaccum) leaf dust. Symbols as in Fig. 1.

\section{DISCUSSION}

Water quality parameters such as temperature, dissolved oxygen, free carbon (iv) oxide, $\mathrm{pH}$, alkalinity and conductivity are parameters that are paramount to the many factors that affect fish health, growth and reproduction (Camus et al., 1998 and Hill, 1955). However, Richards (1977) reported that the main cause of mortality in aquarium fish was the inadequate maintenance of the water environment. In this study the monitored parameters were noted to be significantly different from the control test after the 14 days exposure period which invariably meant that tobacco leaf dust had impact on the water chemistry. According to Omoniyi et al., (2002), sublethal effects of tobacco leaf dust on the haematological parameters of the Clarias gariepinus revealed increased and decreased insignificance difference in the monitored water quality parameters. The variation in the reported result of monitored parameters could be associated to the exposure period and the level of tobacco leaf dust concentrations. Noga, (1996) and Richards (1977) recommended the $\mathrm{pH}$ for fresh water fish to be 6.5 to 8.5 , the value of $\mathrm{pH}$ in the highest concentration of tobacco leaf dust was found to be lower than the recommended value. Thus the significance decrease in $\mathrm{pH}$ value as the concentrations of tobacco leaf dust increased revealed that the toxicant resulted in acidic condition. This was supported by the findings of Omoniyi et al., (2002) who reported acidic condition in water of Clarias gariepinus exposed to tobacco leaf dust. The decline in $\mathrm{pH}$ with time could be due to the production of acidic metabolites (Delyan et al., 1990). Odokuma and Okara (2004) attributed the $\mathrm{pH}$ of various treatments to be a function of the chemical composition of the treatment, which was related to the nature of the carbon source and other nutrients present, thus signifying that tobacco leaf dust had potential of fertilizing the pond as reported by Aleem (1987). The acidic condition of the water had resulted in the decrease in level of dissolved oxygen, free carbon (iv) oxide and temperature with a corresponding increase in the values of total alkalinity and conductivity. Omoniyi et al., (2002) had also reported decrease in the temperature, dissolved oxygen with increase in conductivity values, respectively. The decrease in the available free carbon (iv) oxide may affect the survival of plants, thus reduction of dissolved oxygen results in hypoxia in animal which is as a result of degradation of the tobacco leaf dust. According to Almeida-Val et al., (1993), environment with low dissolved oxygen are found in many tropical plain lakes, ponds, swamps and other eutrophic waters when nutrient potential is introduced.

Total protein is an important constituent of all the cells and tissues which play vital role in the physiology of living organism. Since the fishes have little carbohydrate, protein is used to meet the increase the energy demand. Proteins are mainly involved in the architecture of the cell, which is the chief source of nitrogenous metabolism. 
During chronic periods of stress, proteins are also a source of energy (Umminger, 1977). The decrease in serum total protein reported in this study was supported by the study of Das and Mukherjee (2003) on Labeo rohita exposed to sublethal concentrations of cypermethrin. It would be logical therefore, to suggest that tobacco leaf dust in the present study caused a stress-induced effect on protein synthesis which must have led to the depletion in the serum protein. The decrease in serum total protein level suggested high protein hydrolytic activity due to the elevation of protease activity (Tiwari and Singh, 2003). Tiwari and Singh (2003) reported decrease in serum total protein in snake head fish (Channa punctatus) exposed to sublethal concentrations of lattices of Euphorbia royleana. Reeta et al., (1993) reported inhibition in the total serum protein of an air breathing fish Heteropneustes fossilis after exposure to different pesticides (DDT, YBHC and Malathion). Ravichandran et al., (1994) reported depletion of protein due to proteolysis after exposing Oreochromis mossambicus to nominal concentrations of phenol. Bradbury et al., (1987) pointed out that the decreased protein content might also be attributed to the destruction or necrosis of the cells and consequent impairment in protein synthesis machinery. The quantity of protein is dependent on the rate of protein synthesis, or on rate of its degradation. This may be affected by incorporating the impaired amino acids into polypeptide chains (Ram et. al., 2003). The depletion of protein fraction in liver and kidney tissues may have been due to their degradation and possible utilization for metabolic purpose which may indicate liver and kidney dysfunction (Fafioye et. al., 2005). The depletion of tissue protein-pesticides stress influences the conversion of tissue protein into soluble fraction reacting in the blood for utilization. The significance reduction in liver and kidney total protein may be due to increase energy demand during stress/or altered enzymatic activities (Lett et al., 1976).

Albumin functions as transport proteins for several steroid hormones and for fatty acids from adipose tissue to muscle. It is responsible for about $80 \%$ of the total osmotic regulation. Jee et al., (2005) had reported decrease in serum albumin in Korean rock fish (Sebastes schlegeli) exposed to cypermethrin. The decrease in the value of serum albumin may impede its function of transportation. The significant decrease in serum albumin may have resulted from the inhibitory effect of the plant dust on protein hydrolytic activity due to elevation of protease activity corresponds with the values of total protein. Fafioye et al., (2005) had reported reduced albumin value in the kidney of Oreochromis niloticus exposed to sublethal concentrations of aqueous extract of Raphia vinifera. This study supported the present findings in that fish when exposed to sublethal concentrations of piscicides were stressed. The increased value of liver albumin could be as a result of accumulation of the protein in the liver impeding other functions of the liver.

Globulin is one of the two types of serum protein with large molecules and less soluble in water than albumin. They are involved in the transport of a variety of substances, including lipids, hormones and inorganic ions. The decrease in the value of serum globulin showed that the effect of tobacco leaf dust as an inhibitory agent on hydrolytic activity was due to the elevation of protease activity in the liver. This could be the reason why its value was high in the liver. The decreased globulin value in the kidney was an indication of stress in the fish.

Glucose is an important diagnostic tool of carbohydrate related disorder. It has been proven to be reliable endocrine and physiological indicator of the relative severity of many acute stresses to fish (Soenges et. al., 1992). Carbohydrates are the primary and immediate source of energy. It represents the principal and immediate energy source (Umminger, 1977). The content of glucose in the blood of cultured fishes depends chiefly on the kind of carbohydrate feed. Hyperglycaemia is associated with stressful situations (Fletcher, 1975) and bacterial infections while hypoglycaemia may accompany intensive physical effort (Driedzic and Kicenuik, 1976). Agrahari et al., (2007) reported hyperglycaemia in the plasma of fish Channa punctatus when exposed to sublethal concentrations of monocrotophos for 15 and 60 days. Banaee et al., (2008) reported hyperglycaemia in serum of common carp Cyprinus carpio exposed to sublethal concentrations of diazinon. Similarly, Weiss et al., (1984) reported a pronounced increase in blood sugar level which was going parallel to the inhibition of the cholinesterase and the appearance of manifestation of cholinergic stimulation as a result of parathion intoxication. This increase in serum glucose may be related to stressful condition due the level of insufficient 
dissolved oxygen and the activity of micro organism in the degradation of the plant dust (Fletcher, 1975). The reduced value of liver glucose may be as a result of its inability to perform the function gluconeogenesis effectively.

Triglyceride is important in the diagnostic treatment of disease involving lipid metabolism. Triglycerides are broken to lipolytically glyceride and fatty acid. During exposure periods, the role of glyceride as glucose precursor becomes more important. The liver metabolism changes as well. The liver stops the synthesis glucose while the muscles restrict their ketone utilization to necessitate the energy being supplied via oxidation of fatty acid. The decrease in serum triglyceride was supported by the report of Kori-Siakpere et al. (2007) that paraquat resulted in decrease in plasma triglyceride in Clarias gariepinus after the $96 \mathrm{~h}$ exposure period. This reduction in serum triglyceride suggested that the lipolysis proceeding during exposure period was the major source of energy (Simeno et. al., 1981, Herming and Palezny, 1987 and Friedrich and Stepanowska, 2001).

Cholesterol content in the blood is linked to lipid metabolism and depends on the calorific value of the feed. As a consequence of action of negative environmental factors (stress and pollution), the same fish species exhibited hypercholesterolemia (Perrier et. al., 1972) and also decrease of cholesterol level (Wedemeyer, 1976). Many authors have reported similar result in fish exposed to pesticides. Jee et al., (2005) had reported decrease in serum cholesterol in Korean rock fish (Sebastes schlegeli) exposed to cypermethrin. Agrahari et al., (2007) reported hypocholesteremia in plasma of fish Channa punctatus exposed to sublethal concentrations $(0.96$ and $1.86 \mathrm{mg} / \mathrm{L})$ of monocrotophos for 15 and 60 days. Khurshid (2003) also reported that cholesterol and total lipids decreased in young chick embryo exposed to cypermethrin.

Calcium is essential for bone formation, activity of enzymes, especially those responsible for muscle contraction and for the transmission of nervous impulses. It also facilitates neuromuscular excitability (Aurbach et.al., 1985). Calcium is important in blood coagulation and as regulator of permeability of cell membrane to water and inorganic ions. It also contributes to the maintenance of the membrane potential as well as the development of action potential in muscle and nerves. Atamanalp et al., (2002) reported significant decrease in calcium of Rainbow trout (Oncorhynchus mykiss) exposed to the effect of cypermethrin (A synthetic pyrethroid) after the 15 days exposure period. Low albumin level causes the total serum calcium to drop. Decrease serum calcium levels usually accompany certain kidney disease and low protein levels. The serum level of calcium is greatly affected by the serum level of inorganic phosphate. In most cases, there is an inverse relationship between calcium and inorganic phosphate. The persistent hypocalcaemia observed may be either due to defective intestinal calcium absorption in the renal tubules accompanied by neuromuscular hyper-excitability and cramp condition, indicating hypocalcaemic tetanus, caused by pesticides (Gill et. al., 1988). Hypocalcaemia can be attributed to diffusional losses caused by increased permeability of gill epithelium to water and ions. The total calcium in the serum indicates a directional and range of the ionic - osmotic regulation (Girard, 1976). The present study demonstrated that tobacco leaf dust in sublethal concentration could change osmotic regulation process.

Creatinine leaves the muscle and enters the blood where it is a waste product largely from the muscle breakdown. It is removed by filtration through the glomeruli of the kidney and is excreted as urine. Therefore, it is frequently used in the diagnosis of renal function especially the glomeruli filtration rate (Murray, et. al., 1995). Yakubu et al., (2003) reported significant decrease in serum content of urea and creatinine throughout 15 days exposure period on some functional parameters of rat (200$250 \mathrm{~g}$ ) liver and kidney when exposed to the of yohimbine $(14 \mathrm{mg} / \mathrm{kg}$ body weight) an aphrodisiac. Urea is the principal end product of protein catabolism. It is a waste product metabolized in the liver and excreted by the kidney. Khleifat et al., (2002) reported significant difference in blood urea of rats exposed to chronic effect of ethanolic extract of Teuerium pollum $(20 \mathrm{mg} / \mathrm{kg}$ and $50 \mathrm{mg} / \mathrm{kg}$ ) during the six weeks exposure period. Urea is important in diagnosis or indicator of kidney function. The amount of urea nitrogen in the blood serum is an indicator of protein metabolism. The low value of serum urea may be attributed to the inability of the liver to metabolize protein.

Uric acid is the major product of the catabolism of purine nucleoside (adenosine and guanosine) from the purine metabolism pathway. The reduced value of serum uric acid may be attributed to the 
inability of the liver to synthesize purine. Hypouricaemia an abnormal decrease in uric acid is usually associated with hepatocellular disease, renal re-absorption defect.

\section{CONCLUSION}

Tobacco dust is locally available, inexpensive, easily degraded and serves as piscicides and an organic fertilizer. Tobacco leaf dust may be a useful substitute of synthetic piscicides in killing the weed fish from culture pond. This is environmentally safe because their toxic effect is reversible within three days after application. Its moderate effect and the rapid rate of degradation make it attractive for aquaculture purposes, as a toxicant to control the pest and subsequently as an organic fertilizer. This study showed that the extracts of tobacco leaf exerted piscicidal and fertilizer properties. The result revealed that tobacco leaf dust at studied concentrations had slight effect on the intermediary metabolism of Hybrid catfish. It suggested that sublethal concentrations of tobacco leaf dust at the tested concentrations had some mild effects on some basic function of the serum, liver and kidney of Hybrid catfish. Therefore, the determined biochemical parameters could be suitably used to determine the effect of toxicant on the physiology of fish under sublethal condition prior to sudden death of the fish. The activities of determined biochemical parameters showed mild damage in kidney, liver, plasma membrane, endoplasmic reticulum. However, it has been known to affect the chemistry of the water, thus may primarily affect the primary productivity and the biodiversity of organisms as a result of decrease in the level of dissolved oxygen, free carbon (iv) oxide, temperature and increase in total alkalinity and conductivity

\section{REFERENCES}

Agbon, A.O. Omoniyi, I.I and Teko, A.A. (2002), Acute toxicity of tobacco (Nicotiana tobaccum) leaf dust on Oreochromis niloticus and haematological changes resulting from sublethal exposure. J. Aq. Sci. 17 (1), 5-8.
Agrahari, S. Pandey, K.C. and Gopal, K. (2007), Biochemical alteration induced by monocrotophos in the blood plasma of fish, Channa punctatus (Bloch), P. Biochem and Phys, 88 (3), 268-272.

Akanji, M.A., Olagoke, O.A. and Oloyede, O.B. (1993), Effect of chronic consumption of metabisulphite on the integrity of the rat kidney cellular system. Toxicol., 81, 173-179.

Akehurst, B.C. (1968), Tobacco, Longman, Green and Co, London, pp: 2-11.

Aleem, S.O. (1987), An assessment of tobacco waste for control of the gastropod Tympandonus fuscavis (Linnaeus) in brackish water fish pond. Аquac. 73, 19-25.

Almeida-Val, V.M.F, Val, A.L and Hochachika, P.W. (1993), Hypoxia tolerance in Amazon fishes: status of an under- explored biological 'goldmine'. In: P.W. Hochachka, P.L. Lutz, T. Sick, M. Rosenthal, G. Van der Thillart (eds), Surviving hypoxia: mechanism of control and adaptation. CRC Press, Boca Raton, Chapter 29, pp 436-445

APHA (1998), Standard methods for the examination of water and waste water $20^{\text {th }}$ edition (Revised edition). American Public Health Association, NY USA, pp1076.

Atamanalp, M., Keles, M.S., Halilorglu, H.I. and Aras, M.S. (2002), The effects of cypermethrin (A synthetic pyrethoid) on some Biochemical parameters of $(\mathrm{Ca}$, $\mathrm{P}, \mathrm{Na}$, and TP) of Rainbow trout (Oncorhynchus mykiss) Turk. J. of Biol, 26, 1157-1160.

Aurbach, G.D., Marx, S.J. and Spigel, A.M. (1985), Parathyroid hormone calcitonin and calciferols. In: Wilson, J.D., Foster D.W. (ed), Williams textbook of endocrinology, W.B. Saunders Company Philadelphia, pp:1137-1217.

Banaee, M, Mirvagefei, A.R, Rafei, G.R and Majazi Amiri, B (2008), Effect of sublethal diazinon concentrations on blood plasma biochemistry. Intl $J$ of Environ Res, 2 (2), 189-198

Bradbury, S.P, Symonic, D.M, Coats, J.R and Atchison, G.J (1987), Toxicology of fenvalerate and its constituent's isomers to the fathead minnow (Pimephales promelas) and blue gill minnow (Lepomis macrochirus). Bull. of Environ Contam and Toxicol, 38, 727- 735

Camus, A.C., Burrow, R.M., Hemstreet, W.G., Thure, R.L. and Hawke, J.P. (1998), Aeromonas Bacterial infections - Motile Aeromonas septicemia Southern Regional Aquaculture Centre Publication No.478.

Chapatwala, K., Boykin, M.A. and Rajanna, B. (1982), Effect of intra peritoneally injected cadmium on renal and glycogenic enzymes in the rats. Drug and Chem Toxicol, 5, 305-317. 
Das, B.K and Mukherjee, S.C (2003), Toxicity of cypermethrin in Labeo rohita fingerlings: Biochemical enzymatic and haematological consequences. Comp Biochem and Physiol C. Toxicol and Pharmacol, 134, 109-121

Delyan U, Harder H, and Hopner T.H (1990), Hydrocarbon Biodegradation in Sediments and Soils. A Systematic Examination of Physical and Chemical Conditions Part II. pH Values. Wisseschaft Technik Sci Tech, 43, 337-342.

Driedzic, W.R and Kicenuik, J.W (1976), Blood Lactate levels in free- swimming rainbow trout (Salmo gairdneri) before and after strenuous exercise resulting in fatigue. J. of Fish Res Board Canada, 33, 173-176

Fafioye, O.O., Fagade, S.O. and Adebisi, A.A. (2005), Toxicity of Raphia vinifera P. beauv fruit extracts on biochemical composition of Nile tilapia (Oreochromis niloticus, Trewavas). Biokemistri, 17 (2), 137-142.

FAO (2004), FAO Fisheries circular 886. Rev.25-29 June

FAO (1970), Reclamation of ponds, lakes and streams with fish toxicants: A review. FAO Fish Tech. pap, No. 100

Fletcher, G.L (1975), The effects of capture 'stress' and storage of whole blood on red blood cells, plasma proteins, glucose and electrolytes of the winter flounder (Pseudopleuronectes americanus). Can J of Zool, 53,197-206

Friedrich, M and Stepanowska, K (2001), Effect of starvation on nutritive value of carp (Cyprinus carpio) and selected biochemical components of its blood. Acta Ichthyologica et Piscatoria, 31, 29-36

Gill, R, Foster, A and Woodruff, G (1988), MK-801 in neuroprotective in gerbils when administered during the post ischemic period. Neuroscience, 25, 847-855

Girard, J.P (1976), Salt excretion by the perfused head of trout adapted to sea water and its inhibition by adrenaline. J. of Comp Physiol, 111, 77-91

Hassal, K.A. (1982), The chemistry of pesticides; Macmillan press, London, p372.

Herming, T.A and Palezny, E (1987), Compositional changes in skin mucus and blood serum during starvation of trout. Aquac., 66, 265-273

Hill, A.B. (1995), The environment and disease, Association or Causation? Proc. of the Royal Soc. of Med. pp.295-300

Jee, L.H; Marsroor, F; Kang, J.Ch. (2005), Response of cypermethrin- induced stress in haematological parameters of Korean rockfish, Sebastes schlegeli (Hilgendrof). Aquac. Res, 36, 898-905

Jhingran, V.G., (1975), Fish and Fisheries of India, Hindustan Publishing Corporation (India). pp371.
Jhingran, V.G. (1983), Fish and Fisheries in India, 2nd Edition, Hindustan Publishing Corporation, New Delhi, India.

Katiha, P.K. (2000), Freshwater aquaculture in India: Status, potential and constraints workshop proceeding 7, pp.98-108, National Centre for Agriculture Economics and Policy Research.

Khleifat, K., Shakhanbeh, J. and Tarawneh, K. (2002), The chronic effects of Teuerium pollum on some blood parameters and Histopathology of the liver and kidney in the rat. Turk. J. of Biol, 26, 65-71.

Khurshid, A (2003), Cypermethrin, A pyrethroid insecticides induces tetratological and biochemical changes in young chick embryos. Pak. J. of Biol Sci, 6, 1698-1705

Konar, S.K. (1970), Nicotine as a fish poisons. The Prog. Fish Cult, 32, 103-104.

Kori-Siakpere, O., Adamu, K.M. and Okenabirhie, J. (2007), Sublethal effects of paraquat on some plasma organic constituents (metabolic parameters) of African catfish: Clarias gariepinus (Osteichthyes: Clariidae) Intl J. of Zool Res, 3 (4), 213-217.

Lett, P.F; Farmers, G.J and Beamish, F.W.H (1976), Effect of copper on some aspect of the bioenergetics of Rainbow trout (Salmo gairdneri). J. of Fish. Res Board Can, 33, 1335- 1342

Mahoba, G.P. (1987), Studies on Indian Cichlids Ph.D thesis, University of Science and Technology, Cochin, India.

Murray, R.K, Sranner, D.K, Mayes, P.A and Rodwell, V.W (1995), Biochemia Harpera (Harpers Biochemistry) PZWL, Warszawa (In Polish)

Ngaha, E.O. (1982), Further studies on the in vivo effect of cephalondine on the sterility of rat kidney lysosome. Biochem Pharmacol, 3, 1843-1847.

Noga, E.J. (1996), Fish Disease: Diagnosis and Treatment Mosby Yearbook, Inc. Weslin Industrial Drive; St. Louis, Missouri, 367pp.

Odokuma L.O and Okara J.O (2004), Biodegradability of grounded cell phone recharge cards in two Niger Delta soils. J. of Appl Sci and Eng Tech, 5 (18), 1120.

Ogbu, S.I and Okechukwu, F.I (2001), The effect of storage temperature prior to separation on plasma and serum potassium; J. of Med La ci, 10,1-4

Omoniyi, I.I., Agbon, A.O. and Sodunke, S.A. (2002), Effects of lethal and sublethal concentrations of tobacco (Nicotiana tobaccum) leaf dust extract on weight and haematological changes in Clarias gariepinus (Burchell) J. of Appl Sci and Environ. Mgt, 6 (2), 37-41. 
Perrier, H, Perrier, C, Gudefin, I and Gras, A. (1972). Adrenaline-induced hypercholesterolemia in the rainbow trout Salmo gairdneri Rich, a separate study in male and female trout and the effect of adrenergic blocking agents. Comp. Biochem and Physiol, 43A, 341-347

Radhaiah, V., Girija, M. and Rao, K.J. (1987), Changes in selected biochemical parameters in the kidney and blood of the fish, Tilapia mossambicus (Peters), exposed to heptachlor. Bull. of Environ. Contam. and Toxicol, 39, 1006-1011.

Ram, P.Y, Digvijay, S, Singh, S.K and Singh, A (2003), Metabolic changes in fresh water fish Channa punctatus due to stem-bark extract of Crton tiglium. Pak. J. of Biol. Sci, 6, 1223-1228

Rand, G.M., Wells, P.G. and McCarthy, L.S. (1995), Introduction to aquatic toxicology. In: G.M. Rand (ed), Fundamental of aquatic Toxicology: effects environmental fate and risk assessment. 2nd ed. Taylor and Francis, Washington, D.C

Ravichandran, S, Midhunashanthi, $\mathrm{K}$ and Indira, N (1994), Impact of phenol on protein metabolism in the freshwater fish Oreochromis mossambicus. J. of Ecotoxicol and Environ. Mon., 4, 33-37

Reeta, P, Bhargava, S and Saraf, D.K (1993), Toxic effects of some biocides on total serum protein in Heteropneustes fossilis. Ind. J. of Environ. Toxicol, 3, 5-6

Richards, R. (1977), Disease of Aquarium Fish 1. Vet. Rec. 101, 166-167.
Simeno, S, Takeda, M, Takayama, S, Fukui, A, Sasaki, $\mathrm{H}$ and Kajiyama, $\mathrm{H}$ (1981), Adaptation of hepatopancreatic enzymes to dietary carbohydrate in carp. Bull. of Jap. Soc. of Sci. Fish, 47, 71-77

Soenges, J.L., Rey, P., Rozas, G., Andres, M.D. and Aldegunde, M. (1992), Effects of cortisol and thyroid hormone treatment on the glycogen metabolism of selected tissues of domesticated rainbow trout Oncorhynchus mykiss Aquac., 101, 317-328.

Tiwari, S. and Singh, A. (2003), Metabolic changes in the Snake head fish Channa punctatus, due to lattices of Euphorbia royleana, Asian Fish. Sci., 16, 147-155.

Tobor, J.G. (1990), The Fishing Industry in Nigeria: Status and potential for self sufficiency in fishing production, NIOMR, Technical Paper, No.54 Nigeria Institute for Oceanography Research, Lagos, Nigeria, $26 \mathrm{p}$.

Vogues, E. (1984), Tobacco Encylopaedia, Tobacco Journal International Federal Republic of Germany, all pages.

Weiss, I.R, Bryant, L, and Filzhygh, O.G (1984), Blood sugar levels following acute poisoning with parathion and I-naphthyl N-methyl carbamate (sevin in three species. Toxicol. and Appl Pharmacol, 6, 363-369

Yakubu, M.T., Bilbis, L.S., Lawal, M. and Akanji, M.A. (2003), Evaluation of selected parameters of rats' liver and kidney function following repeated administration of yohimbine Biokemistri, 15 (2), 50b56. 